\title{
Carcass Characteristics and Meat Quality of Kiko Crossbred Male Goats as Influenced by Feeding Phytochemical Tanning Containing Supplementations
}

\author{
Jung Hoon Lee ${ }^{1 *}$, Byeng Ryel Min² \\ ${ }^{1}$ Georgia Small Ruminant Research and Extension Center, Fort Valley State University, Fort Valley, USA \\ ${ }^{2}$ Animal and Poultry Sciences, Tuskegee University, USA \\ Email: ^leej@fvsu.edu
}

How to cite this paper: Lee, J.H. and Min, B.R. (2021) Carcass Characteristics and Meat Quality of Kiko Crossbred Male Goats as Influenced by Feeding Phytochemical Tanning Containing Supplementations. Agricultural Sciences, 12, 445-463.

https://doi.org/10.4236/as.2021.125029

Received: March 10, 2021

Accepted: May 11, 2021

Published: May 14, 2021

Copyright $\odot 2021$ by author(s) and Scientific Research Publishing Inc. This work is licensed under the Creative Commons Attribution International License (CC BY 4.0).

http://creativecommons.org/licenses/by/4.0/

(c) (i) Open Access

\begin{abstract}
This research assessed the effect of incorporating condensed tannin-rich pine bark (PB) and sericea lespedeza (SL) into meat goats' diets on carcass traits, chemical composition, and meat quality of goat meat (chevon). Meat goats were supplemented with bermudagrass hay (BG-diet, control), SL, PB, or 1:1 mixture of SL and PB (SL + PB-diet), with the remainder of each diet made up of $70 \%$ alfalfa pellets mixed with a commercial corn-based sweet feed. Furthermore, four experimental diets provided a total of 4.9, 40.1, 49.0, or $45.0 \mathrm{~g}$ of condensed tannins, CT/kg DM, respectively. Carcass traits were assessed after the slaughter at the end of $50 \mathrm{~d}$ feeding period. After $24 \mathrm{~h}$ cooler storage $\left(2^{\circ} \mathrm{C}\right)$, edible tissues were collected from each carcass for analyzing meat quality parameters. No significant differences were found in carcass traits and primal cuts among goats fed the experimental diets. Supplementing goats with wood-derived condensed tannins (pine bark) produced redder (higher CIE $\mathrm{a}^{*}$ values; $P<0.003$ ), tenderer (lower Warner-Bratzler shear force values; $P<0.002$ ), and healthier (higher linoleic and $\alpha$-linolenic acids; $P$ $<0.03)$ chevon than that from goats fed either forage-derived (sericea lespedeza) or combined condensed tannins (1:1 mixture of sericea lespedeza and pine bark). Our findings indicate that either forage-, wood-derived condensed tannins, or their combined one can be used as a dietary supplement since they do not have any detrimental effect on meat goats' performances and meat quality characteristics of chevon. Furthermore, feeding meat goats with wood-derived condensed tannins probably produced tenderer and healthier chevon than that from meat goats fed either forage-derived only or combined with forage and wood derived-condensed tannins.
\end{abstract}




\section{Keywords}

Goats, Condensed Tannins, Sericea Lespedeza, Pine Bark, Meat Quality

\section{Introduction}

Meat goat production has steadily increased in the southern US because of the availability of forages and rising market demand that is providing additional income on diversified farming [1] [2]. In general, feeding cost makes up to $70 \%$ of the total expenditures in livestock production [3]. Meat goat producers, thereupon, need economical and easily manageable feedstuffs. Furthermore, infection with gastrointestinal nematodes (GIN) also is an economic burden to the production of meat goats in the southern United States (US) [4]. Either condensed tannins (CT)-rich pine bark (PB, Pinus taeda L.) or sericea lespedeza (SL, Lespedeza cuneate) has been suggested as an alternative parasites control strategy to suppress GIN infection because frequent use of board-spectrum anthelmintic drugs to control small ruminant GIN has led to greatly increased incidence of anthelmintic resistance worldwide [5] [6] [7]. As low-input forage, SL is an economical feed resource in the southern region [8] in the US. However, pine bark (PB; 13\% CT DM) is a by-product of the timber industry [9]. Clearly, either ground $\mathrm{PB}$ or wood chips have been exercised as roughages in livestock feed [10]. Rather, the feeding values of SL and PB are considered to be low because of their relatively high concentration of CT [7] [11].

Plant tannins exist primarily in hydrolyzable tannins (HT) and condensed tannins (CT). CT are phenolic compounds found in a variety of legume forages and tree leaves, which commonly contain catechin, procyanidin, and other polymeric procyanidins [12]. Unlike HT, CT have either a beneficial or detrimental effect on animal performance that is depending on the concentration and nature of CT [13]. Low concentrations of CT ( $2.0 \%$ to $4.9 \%$ DM) can improve ruminal animal performance without detrimental effects by reducing protein degradation in the rumen and increasing the flow of protein and essential amino acids to the intestine, subsequently [14]. Improved nutritional utilization and animal performance, as well as reduced internal parasite infection in ruminants consuming either CT-derived from forages or wood chips, have been reported [5] [6] [7] [11]. As indicated in their reports, both CT-rich PB (wood chips) and SL (forages) are economical and easily manageable feed ingredients for small ruminants. However, the impacts of feeding a combination of these two different types of CT-rich feeding ingredients on animal performance and digestibility in meat goats are unknown and need to be determined. There is a possibility to enhance the beneficial effects of CT on microbial physiology in the rumen because of the extent of phenolic metabolites derived from mixed CT. Compared with other ruminants, goats are more easily utilized in plants containing a relatively highlevel CT because they can be readily induced by dietary tannins to produce a 
tannin-binding protein in saliva that carries tannin-tolerant bacteria to overcome the negative impacts of CT on digestibility in the rumen. Hence, there is a potential to use a mixed CT-rich PB and SL as roughages in meat goats' feedstuffs.

Different forms and energy levels of diets influence carcass composition and meat properties in food animals [15]. Condensed tannins (CT) are phenolic compounds that might limit the ruminal biohydrogenation of unsaturated dietary fat during digestion and prevent the oxidation of meat due to their antioxidant properties [9]. Therefore, feeding CT containing supplements to ruminants may increase unsaturation and antioxidant properties in their edible tissues. The objective of this research was to determine the effect of incorporating CT-rich PB and SL into meat goats' diets on carcass traits, chemical composition, and meat quality of chevon, as well as on body and muscle fats of meat goats.

\section{Materials and Methods}

The animals exercised in this study were managed according to the Live Animal Use in Research Guidelines of the Institutional Animal Care and Use Committee of the Tuskegee University (Tuskegee, AL, USA). Twenty-four Kiko crossbred (Capra hircus) intact male goats (BW = 37.3 $\pm 2.56 \mathrm{~kg}$; approximately 8 months of age) were assigned randomly to a corn basal diet supplemented with either: 1 ) bermudagrass hay; 2) sericea lespedeza (SL, Lespedeza cuneate); 3) pine bark (PB, Pinus taeda L.); or 4) mixed SL and PB (Table 1). The proportions of corn basal diet composed predominantly of cracked corn and alfalfa meal were identical in all diets. Both SL and bermudagrass were harvested at roughly $60 \mathrm{~cm}$ height from pure stands. The concentrations of condensed tannins (CT) in SL and berumdagrass hays were around $6.5 \%$ and $0.8 \%$ on a dry matter (DM) basis, respectively. Freshly air-dried PB containing approximately $10.3 \%$ CT on DM was ground with a Hammer Mill (Model No. 1250; Lorenz MFG Co., Benson, $\mathrm{MN}$, USA) to roughly 3-mm particle size before preparing dietary supplements. Goats were individually housed indoors in pens of approximately $1.2 \mathrm{~m}^{2}$ with elevated floors and initially fed at $4 \%$ of their body weight (BW) once daily, with feed offered, orts recorded, and adjustments made daily to allow $10 \%$ feed refusal, with ad libitum access to water for 50 days.

At the conclusion of feeding trial, goats were transported and harvested at a USDA-approved abattoir at the Fort Valley State University (Fort Valley, GA, USA) using standard procedures. Hot carcass weight (HCW) was recorded on the day of slaughter, and carcasses were chilled at $2^{\circ} \mathrm{C}$ for $24 \mathrm{~h}$. Subsequently, cold carcass weight (CCW) and carcass shrink were also determined. Dressing percentage (DP) also reported as that proportion of the live weight that remains in the carcass. Ultimate muscle $\mathrm{pH}$ was measured between the 12th and 13th ribs at 24-h postmortem using a portable $\mathrm{pH}$ meter (Fisher Scientific, Pittsburgh, PA, USA) with a penetrating probe (Pakton Model OKPH1000N, Fisher Scientific). On day 2 postmortem, carcasses were fabricated into primal cuts, and each portion of primal cuts was recorded. Furthermore, three different fat depots such as 
Table 1. Ingredient and nutrient composition of experimental diets fed to Kiko crossbred intact male goats.

\begin{tabular}{|c|c|c|c|c|}
\hline \multirow{2}{*}{ Item } & \multicolumn{4}{|c|}{ Diet $^{a}$} \\
\hline & BG & SL & $\mathrm{PB}$ & $\mathrm{SL}+\mathrm{PB}$ \\
\hline \multicolumn{5}{|l|}{ Ingredient, \% } \\
\hline Cracked corn & 50.0 & 50.0 & 50.0 & 50.0 \\
\hline Alfalfa meal & 10.0 & 10.0 & 10.0 & 10.0 \\
\hline Soybean meal & 5.0 & 5.0 & 5.0 & 5.0 \\
\hline Molasses & 3.5 & 3.5 & 3.5 & 3.5 \\
\hline Vitamin and mineral $\mathrm{mix}^{\mathrm{b}}$ & 1.0 & 1.0 & 1.0 & 1.0 \\
\hline Salt & 0.5 & 0.5 & 0.5 & 0.5 \\
\hline Bermudagrass hay, BG & 30.0 & - & - & - \\
\hline Sericea lespedeza, SL & - & 30.0 & - & 15.0 \\
\hline Pine bark, $\mathrm{PB}$ & - & - & 30.0 & 15.0 \\
\hline \multicolumn{5}{|l|}{ Nutrient composition, \% DM } \\
\hline Crude protein, $\mathrm{CP}$ & 14.8 & 16.0 & 13.0 & 14.7 \\
\hline Ether extract & 3.11 & 4.13 & 3.35 & 3.65 \\
\hline Ash & 9.10 & 10.2 & 9.97 & 10.0 \\
\hline Acid detergent fiber, $\mathrm{ADF}$ & 30.7 & 33.3 & 34.5 & 30.7 \\
\hline Neutral detergent fiber, NDF & 48.6 & 42.9 & 51.6 & 45.6 \\
\hline Nonfiber carbohydrate, NFC & 28.7 & 26.8 & 23.0 & 25.8 \\
\hline Condensed tannins, CT & 0.49 & 4.01 & 4.90 & 4.50 \\
\hline \multicolumn{5}{|l|}{ Fatty acid, \% } \\
\hline C12:0 & 0.08 & 0.07 & 0.20 & 0.14 \\
\hline C14:0 & 0.52 & 0.51 & 0.71 & 0.61 \\
\hline C14: $\ln 5$ & 0.12 & 0.12 & 0.11 & 0.11 \\
\hline $\mathrm{C} 16: 0$ & 22.58 & 22.39 & 20.80 & 21.63 \\
\hline C16: $\ln 7$ & 4.39 & 5.23 & 4.26 & 4.76 \\
\hline C18:0 & 6.15 & 5.24 & 6.75 & 5.97 \\
\hline C18: $\ln 9$ & 35.69 & 35.83 & 36.65 & 36.23 \\
\hline $\mathrm{C} 18: 2 \mathrm{n} 6$ & 26.56 & 26.64 & 26.68 & 26.66 \\
\hline $\mathrm{C} 18: 3 \mathrm{n} 3$ & 3.91 & 3.96 & 3.84 & 3.90 \\
\hline
\end{tabular}

${ }^{a} \mathrm{BG}=$ basal diet $(\mathrm{BD})$ supplemented with bermudagrass hay; $\mathrm{SL}=\mathrm{BD}$ supplemented with sericea lespedeza; $\mathrm{PB}=\mathrm{BD}$ supplemented with pine bark; SL $+\mathrm{PB}=\mathrm{BD}$ supplemented with combined SL and $\mathrm{PB} .{ }^{\mathrm{b}} \mathrm{Composi}-$ tion: $\mathrm{Ca}, 9.0 \%$; P, 8.0\%; NaCl, 41\%; K, 0.1\%; Cu, 17,500 mg/kg; Se, 25 mg/kg; Zn, 7500 mg/kg; vitamin A, $308,000 \mathrm{IU} / \mathrm{kg}$; vitamin D, 24,200 IU/kg; vitamin E, $1650 \mathrm{IU} / \mathrm{kg}$.

subcutaneous, intramuscular, and kidney fats were also collected from each carcass for fatty acid analysis. Longissimus muscle (LM; intramuscular fat) and subcutaneous fat were excised and removed, respectively, from the loin area, and 
kidney fat was also obtained from each carcass. All fat samples were individually ground in liquid nitrogen, placed in polyethylene bags (NASCO Inc., Fort Atkinson, WI, USA), and stored at $-28^{\circ} \mathrm{C}$ for further analysis. Loin from each carcass was sliced into $2.5-\mathrm{cm}$ loin chops and then used to measure fresh meat color (CIE $\mathrm{L}^{*} \mathrm{a}^{*} \mathrm{~b}^{*}$ ), Warner-Bratzler shear force (WBSF) values, and cooking losses.

The Commission Internationanle de I'Eclairage (CIE) $\mathrm{L}^{\star}$ (lightness) $\mathrm{a}^{\star}$ (red/ green value) $b^{\star}$ (blue/yellow value) color space notation was used to present the color coordinate values of fresh chevon, which were measured on the surfaces of four loin chops from each carcass after a 45 -min bloom time at $4^{\circ} \mathrm{C}$ using a HunterLab Color instrument (Minolta Chromameter, Model CR-200, Minolta, Japan) with illuminant D65 as a light source. After measuring color coordinate values, the four chops were cooked according to the procedures described by Lee et al. [9]. The difference in weight of chops before and after cooking was reported as a percentage of cooking loss. Two cores were taken from each cooked chop and Warner-Bratzler shear force (WBSF) values were assessed using a TA-XT2 texture analyzer fitted with a Warner-Bratzler shear attachment (Texture Technologies Corp., Scarsdale, NY, USA).

Myoglobin and percent metmyoglobin (MetMb) contents were determined using the ground LM sample (5.0 g) according to the method of Krywicki [16]. Myoglobin and MetMb contents were measured at 525, 572, and $700 \mathrm{~nm}$ using a Shimadzu (model UV-2401 PC) spectrophotometer, and the concentrations of myoglobin (mg/g muscle) and MetMb (\%) were calculated using Krywicki's equation [16]. The thiobarbituric acid reactive substances (TBARS) assay was performed on the ground Longissimus muscle (LM) sample (0.5 g) as described by Buege and Aust [17] using 1,1,3,3-tetramethoxypropane (TMP) for preparation of a standard curve of malondialdehyde (MDA). The TBARS were calculated from the standard curve of MDA and expressed as mg MDA/kg sample.

Proximate composition of LM samples was analyzed according to Association of Official Analytical Chemists (AOAC) methods [18]. Total lipids were extracted from $3.0 \mathrm{~g}$ of LM or $0.1 \mathrm{~g}$ of fat depot samples with chloroform/methanol $(2: 1 \mathrm{v} / \mathrm{v})$, using a homogenizer (Cyclone IQ $^{2}$, Virtis Co., Gardiner, NY, USA) for $3 \times 30 \mathrm{~s}$ at 30,000 rpm [19]. Extracted lipid was saponified and esterified according to the American Oil Chemists' Society (AOCS) method [20] of preparation of fatty acid methyl esters (FAME). The prepared FAME were analyzed using a Thermo Electronic (Austin, TX, USA) gas chromatography (Model TRACE GC Ultra) equipped with an automatic sampler Model AS-3000 (Thermo Electronic Co.). A $0.25-\mathrm{mm}$ i.d. by $60-\mathrm{m}$ long fused silica SP-2380 capillary column (Supelco, Inc., Bellefonte, PA, USA) was used to separate the methyl esters, which were detected with a flame ionization detector (FID). The injection temperature was $240^{\circ} \mathrm{C}$ and the column temperature was programmed from $130^{\circ} \mathrm{C}$ to $220^{\circ} \mathrm{C}$ at $4^{\circ} \mathrm{C} / \mathrm{min}$. Helium was the carrier gas, with a flow rate of 1.6 $\mathrm{mL} / \mathrm{min}$ and a split ratio of 30:1. The identification and quantitation of individ- 
ual FAME in the sample were also completed according to the AOCS method [20]. Fatty acids were identified by matching their retention times with those of known standards (Sigma Chemical Co., St. Louis, MO) including decanoic (C10:0), lauric (C12:0), tridecanoic (C13:0), tridecenoic (C13: 1n9), myristic (C14:0), myristoleic (C14: 1n5), pentadecanoic (C15:0), palmitic (C16:0), iso-palmitic (C16:0, iso), palmitoleic (C16: 1n7), trans-7-hexadeanoic (C16: 1n7, trans), margaric (C17:0), heptadecanoic (C17: 1n7), stearic (C18:0), oleic (C18: 1n9), elaidic (C18: $1 \mathrm{n} 9$, trans), vaccenic (C18: $1 \mathrm{n} 11$, trans), linoleic (C18: 2n6), conjugated linoleic (C18:2, CLA), $\alpha$-linolenic (C18: 3n3), eicosanic (C20:0), 11-eicosenoic (C20: 1n9), eicosatrienoic (C20: 3n6), arachadonic (C20: 4n6), eicosapentaenoic (C20: 5n3), docosanoic (C22:0), and docosatrienoic (C22: 5n3) acids.

All data were analyzed as a completely randomized design using the GLM procedure of SAS (SAS Inst. Inc., Cary, NC, USA), with individual goats as the experimental units. Least squares means were generated and separated using the PDIFF options of SAS (pairwise $t$-test). Significant effects were determined at $P$ $<0.05$, but differences with $P<0.1$ were considered as trends.

\section{Results}

Average daily gain (ADG) of the experimental goats was not significantly different among four different supplementation groups. The ADG was 147.4, 85.7, 75.5, and $83.5( \pm 24.95) \mathrm{g} / \mathrm{d}$ for bermudagrass hay (BG)-, sericea lespedeza (SL)-, pine bark (PB)-, and mixed SL and PB-supplements ( $\mathrm{SL}+\mathrm{PB})$, respectively. Subsequently, no significant differences were found in the finial live weight of the goats supplemented with control (BG), SL, PB, or mixed diet (44.9, 41.8, $36.5,42.2 \pm 2.73 \mathrm{~kg}$ ). Accordingly, no significant differences were found in the carcass traits of goats fed four different supplemented diets (Table 2). There were no differences $(P>0.10)$ in mean weights of any of primal cuts, fasting live, hot and cold carcass, as well as in carcass shrinkages, dressing percentages, and loin areas among goats fed the four different dietary supplements.

In this study, ultimate $\mathrm{pH}$ in the longissimus muscle (LM) was not significantly different among goats fed the four different supplements (Table 3 ). However, significant differences were found in all three CIE L* (lightness), $a^{*}$ (redness) and $\mathrm{b}^{*}$ (yellowness) color coordinate values of the LM from goats fed the four different dietary supplements (Table 3 ). The LM from goats supplemented with pine bark $(\mathrm{PB})$ had higher $(P<0.05)$ CIE L*, $\mathrm{a}^{*}$ and $\mathrm{b}^{*}$ values than that from goats fed with other three supplements. There were no differences $(P>$ $0.10)$ found in myoglobin $(\mathrm{Mb})$ contents in the LM from goats fed the four different dietary supplements (Table 3 ). The LM from goats fed the PB supplemented diet had higher $(P<0.05)$ MetMb concentrations and thiobarbituric acid reactive substances (TBARS) values than that from goats fed other three supplemented diets. There were no dietary supplementation effects on meat water holding capacity as measured by cooking loss (Table 3). However, significant 
Table 2. Least squares means $(n=6)$ for selected carcass traits in Kiko crossbred intact male goats fed different dietary supplements containing concentrated tannins (CT).

\begin{tabular}{cccccc}
\hline \multirow{2}{*}{ Item } & \multicolumn{5}{c}{ Diet $^{\mathrm{a}}$} \\
\cline { 2 - 6 } & BG & SL & PB & SL + PB & SE \\
\hline Fasting live weight, $\mathrm{kg}$ & 41.55 & 37.35 & 33.68 & 38.67 & 2.796 \\
Hot carcass weight, $\mathrm{kg}$ & 16.69 & 16.03 & 13.83 & 15.99 & 1.419 \\
Cold carcass weight, kg & 15.78 & 15.14 & 12.98 & 15.09 & 1.379 \\
Carcass shrink, \% & 5.54 & 5.58 & 6.23 & 5.58 & 0.458 \\
Dressing percentage, \% & 40.13 & 42.76 & 41.07 & 40.94 & 0.865 \\
Loin area, cm ${ }^{2}$ & 13.93 & 13.87 & 11.87 & 13.74 & 0.920 \\
\hline Primal cuts, kg & & & & & \\
Neck & 1.57 & 1.41 & 1.26 & 1.45 & 0.149 \\
Shoulder & 1.72 & 1.69 & 1.31 & 1.79 & 0.228 \\
Fore shank & 3.20 & 3.10 & 2.75 & 2.94 & 0.225 \\
Breast and Rack & 2.56 & 2.41 & 1.98 & 2.45 & 0.248 \\
Loin & 1.00 & 0.99 & 0.94 & 1.05 & 0.121 \\
Frank & 0.75 & 0.73 & 0.51 & 0.71 & 0.009 \\
Leg & 4.07 & 3.95 & 3.48 & 3.80 & 0.367 \\
Hind shank & 0.85 & 0.84 & 0.72 & 0.87 & 0.067 \\
\hline
\end{tabular}

${ }^{a} \mathrm{BG}=$ basal diet $(\mathrm{BD})$ supplemented with bermudagrass hay; $\mathrm{SL}=\mathrm{BD}$ supplemented with sericea lespedeza; $\mathrm{PB}=\mathrm{BD}$ supplemented with pine bark; $\mathrm{SL}+\mathrm{PB}=\mathrm{BD}$ supplemented with combined $\mathrm{SL}$ and $\mathrm{PB}$. Within a row, least squares means that do not have a common letter differ $(P<0.05)$.

Table 3. Least squares means $(n=6)$ for quality characteristics of loin chops from Kiko crossbred intact male goats fed different dietary supplements ${ }^{\mathrm{a}}$ containing concentrated tannins (CT).

\begin{tabular}{cccccc}
\hline \multirow{2}{*}{ Parameter } & \multicolumn{5}{c}{ Loin chop } \\
\cline { 2 - 6 } Fresh & BG & SL & PB & SL + PB & SE \\
\hline L $^{*}$ value & $38.74^{\mathrm{e}}$ & $38.36^{\mathrm{e}}$ & $42.40^{\mathrm{d}}$ & $39.32^{\mathrm{e}}$ & 0.787 \\
$\mathrm{a}^{\star}$ value & $11.72 \mathrm{~d}^{\mathrm{e}}$ & $10.89^{\mathrm{e}}$ & $12.65^{\mathrm{d}}$ & $11.06^{\mathrm{e}}$ & 0.405 \\
$\mathrm{~b}^{*}$ value & $9.78^{\mathrm{e}}$ & $9.20^{\mathrm{e}}$ & $11.70^{\mathrm{d}}$ & $9.65^{\mathrm{e}}$ & 0.149 \\
Myoglobin, mg/g & 4.99 & 5.40 & 4.04 & 4.25 & 0.674 \\
Metmyoglobin, \% & $33.41^{\mathrm{e}}$ & $31.91^{\mathrm{e}}$ & $42.50^{\mathrm{d}}$ & $31.22^{\mathrm{e}}$ & 2.536 \\
TBARS, mg MDA/kg & $0.45^{\mathrm{e}}$ & $0.35^{\mathrm{e}}$ & $0.82^{\mathrm{d}}$ & $0.34^{\mathrm{e}}$ & 0.109 \\
Ultimate pH & 5.60 & 5.95 & 5.47 & 5.69 & 0.164 \\
\hline Cooked & & & & & \\
Cooking loss, \% & 23.81 & 16.08 & 16.57 & 16.32 & 3.294 \\
WBSF ${ }^{\mathrm{c}}, \mathrm{kg} / \mathrm{cm}^{3}$ & $3.74^{\mathrm{d}}$ & $3.26^{\mathrm{e}}$ & $3.03^{\mathrm{e}}$ & $3.41^{\mathrm{de}}$ & 0.130 \\
\hline
\end{tabular}

${ }^{\mathrm{a}} \mathrm{BG}=$ basal diet $(\mathrm{BD})$ supplemented with bermudagrass hay; $\mathrm{SL}=\mathrm{BD}$ supplemented with sericea lespedeza; $\mathrm{PB}=\mathrm{BD}$ supplemented with pine bark; $\mathrm{SL}+\mathrm{PB}=\mathrm{BD}$ supplemented with combined $\mathrm{SL}$ and $\mathrm{PB} .{ }^{\mathrm{b}} \mathrm{TBARS}=$ thiobarbituric acid reactive substances calculated as milligrams melondialdehyde per $\mathrm{kg}$ of fresh sample. ${ }^{c}$ WBSF $=$ Warner-Bratzler shear force values. ${ }^{\mathrm{d}, \mathrm{e}} \mathrm{W}$ ithin a row, least squares means that do not have a common letter differ $(P<0.05)$. 
differences were found in the Warner-Bratzler shear force (WBSF) values of loin chops from goats fed the four different dietary supplements. Chops from goats fed the control (BG-supplement), containing negligible amounts of CT, had higher $(P<0.002)$ WBSF values than those from goats fed either SL- or PB-supplement, containing relatively high amounts of CT.

Proximate compositions of LM from goats fed the four different experimental diets are presented in Table 4 . No differences $(P>0.10)$ were observed in mean levels of moisture between goats supplemented with negligible amounts of CT (BG or control diet) and those supplemented with three different CTcontaining dietary supplements (SL, PB and SL $+\mathrm{PB}$ ), whereas goats fed with PB-supplementation had lower $(P<0.05)$ moisture contents in the LM than those fed with the mixed CT $(\mathrm{SL}+\mathrm{PB})$ supplementation. Mean concentrations of ash in the LM of goats fed the mixed CT diet were higher $(P<0.03)$ than in the LM of goats fed the control diet; however, no significant differences were found in ash concentration among goats fed the control, SL, and PB diets. Additionally, no differences $(P>0.10)$ were found in the crude protein and fat contents in the LM of goats fed the experimental diets.

Fatty acids identified in the intramuscular fat of longissimus muscle (LM) from goats fed with four different dietary supplements consisted of eight saturated (SFA: C12:0, C14:0, C16:0 iso, C16:0, C17:0, C18:0, C20:0, and C22:0), seven monounsaturated (MUFA: C14: 1n5, C16: 1n7 trans, C16: 1n7, C18: 1n9 trans, C18: 1n9, C18: $1 \mathrm{n} 11$ trans, and C20: 1n9), and six polyunsaturated (PUFA: C18: 2n6, C18:2 CLA, C18: 3n3, C20: 4n6, C20: 5n3, and C22: 5n3) fatty acids (Table 4). No differences $(P>0.10)$ were found in the concentrations of individual SFA and MUFA with $\mathrm{C} 12$ and $\mathrm{C} 17$ carbon chains in the intramuscular (LM) fat among goats fed the four different supplementations, whereas long chain fatty acids with $\mathrm{C} 18$ to $\mathrm{C} 22$ carbon chains were significantly influenced by the CT-containing dietary supplementations. Goats fed either SL or PB supplement containing relatively high amounts of CT had a lower $(P<0.05)$ percentage of C18:0 in LM than those fed the BG supplement (control) containing negligible amounts of CT, but mean percentage of eicosanic (C20:0) in the LM from goats fed PB supplement was higher $(P<0.05)$ than that from goats fed the control supplement. Furthermore, no significant differences were found in the concentrations of C18:0 and C20:0 in the LM among goats fed CT-containing supplements (SL-, PB-, and SL + PB-diet). Mean concentrations of elaidic (C18: 1n9 trans), vaccenic (C18: $1 \mathrm{n} 11$ trans), C18: 2n6 and $\alpha$-linolenic (C18: 3n3) acids of the LM of goats consuming the PB supplement were higher $(P<0.05)$ than that of goats fed the BG supplement (control). Furthermore, goats fed the PB supplement also had a higher $(P<0.05)$ concentration of C18: $2 \mathrm{n} 6$ in the LM than those fed the SL supplement. No differences $(P>0.10)$ were detected in the concentrations of C18: $1 \mathrm{n} 9$ trans, C18: $1 \mathrm{n} 11$ trans and C18: 3n 3 in the LM of goats fed supplements containing relatively high amounts of CT. Mean concentrations of C18: $1 \mathrm{n} 9$, eicosenic (C20: $1 \mathrm{n} 9)$, eicosapentaenoic (C20: 5n3), and docosatrienoic (C22: $5 \mathrm{n} 3)$ acids in LM were not different $(P>0.10)$ between the control 
Table 4. Least squares means $(n=6)$ for proximate and fatty acid composition (weight percent of fatty acid methyl esters) of longissimus muscle (intramuscular fat) from Kiko crossbred intact male goats fed different dietary supplements containing concentrated tannins (CT).

\begin{tabular}{|c|c|c|c|c|c|}
\hline \multirow{2}{*}{ Parameter } & \multicolumn{5}{|c|}{ Diet $^{a}$} \\
\hline & BG & SL & $\mathrm{PB}$ & $\mathrm{SL}+\mathrm{PB}$ & SE \\
\hline \multicolumn{6}{|c|}{ Proximate composition, \% } \\
\hline Moisture & $76.39^{\mathrm{bc}}$ & $76.82^{\mathrm{bc}}$ & $75.07^{\mathrm{c}}$ & $77.40^{\mathrm{b}}$ & 0.562 \\
\hline Crude protein & 21.41 & 20.93 & 21.56 & 21.01 & 0.227 \\
\hline Ether extracted & 1.54 & 1.67 & 1.41 & 1.18 & 0.185 \\
\hline Ash & $1.06^{\mathrm{c}}$ & $1.11^{\mathrm{bc}}$ & $1.16^{\mathrm{bc}}$ & $1.18^{\mathrm{b}}$ & 0.029 \\
\hline \multicolumn{6}{|l|}{ Fatty acid, \% } \\
\hline $\mathrm{C} 12: 0$ & 0.90 & 0.95 & 0.97 & 0.80 & 0.072 \\
\hline $\mathrm{C} 14: 0$ & 6.47 & 6.08 & 7.43 & 6.78 & 0.830 \\
\hline C14: $1 \mathrm{n} 5$ & 0.25 & 0.23 & 0.38 & 0.23 & 0.042 \\
\hline $\mathrm{C} 16: 0$, iso & 0.58 & 0.60 & 0.48 & 0.45 & 0.067 \\
\hline $\mathrm{C} 16: 0$ & 16.62 & 17.27 & 16.16 & 16.40 & 0.512 \\
\hline C16: 1n7, trans & 0.81 & 1.03 & 0.94 & 0.87 & 0.054 \\
\hline C16: $\ln 7$ & 2.01 & 1.58 & 2.19 & 2.20 & 0.182 \\
\hline $\mathrm{C} 17: 0$ & 1.06 & 1.11 & 1.24 & 0.96 & 0.068 \\
\hline C18:0 & $16.93^{b}$ & $15.01^{\mathrm{c}}$ & $14.93^{c}$ & $15.33^{\mathrm{bc}}$ & 0.505 \\
\hline C18: $1 \mathrm{n} 9$, trans & $1.97^{\mathrm{d}}$ & $2.30^{\mathrm{cd}}$ & $3.20^{\mathrm{b}}$ & $2.74^{\mathrm{bc}}$ & 0.161 \\
\hline C18: $\ln 9$ & $36.89^{\mathrm{bc}}$ & $38.32^{\mathrm{b}}$ & $32.62^{c}$ & $33.96^{\mathrm{bc}}$ & 1.169 \\
\hline C18: $1 \mathrm{n} 11$, trans & $0.94^{\mathrm{d}}$ & $1.03^{\mathrm{cd}}$ & $1.09^{\mathrm{b}}$ & $1.08^{\mathrm{bc}}$ & 0.036 \\
\hline $\mathrm{C} 18: 2 \mathrm{n} 6$ & $5.56^{\mathrm{c}}$ & $6.19^{c}$ & $8.21^{\mathrm{b}}$ & $7.65^{\mathrm{bc}}$ & 0.582 \\
\hline $\mathrm{C} 18: 2, C L A$ & 0.72 & 0.76 & 0.81 & 0.80 & 0.044 \\
\hline C18: 3n3 & $0.57^{\mathrm{c}}$ & $0.74^{\mathrm{bc}}$ & $0.91^{\mathrm{b}}$ & $0.82^{\mathrm{b}}$ & 0.046 \\
\hline $\mathrm{C} 20: 0$ & $0.89^{c}$ & $0.96^{\mathrm{bc}}$ & $1.11^{\mathrm{b}}$ & $0.92^{\mathrm{bc}}$ & 0.074 \\
\hline C20: $\ln 9$ & $0.67^{\mathrm{bc}}$ & $0.49^{c}$ & $0.67^{\mathrm{bc}}$ & $0.77^{\mathrm{b}}$ & 0.052 \\
\hline C20: 4n6 & 2.53 & 2.12 & 2.81 & 3.00 & 0.215 \\
\hline C20: $5 \mathrm{n} 3$ & $0.38^{\mathrm{bc}}$ & $0.35^{\mathrm{c}}$ & $0.44^{\mathrm{b}}$ & $0.32^{\mathrm{c}}$ & 0.015 \\
\hline $\mathrm{C} 22: 0$ & 2.18 & 1.82 & 2.27 & 2.42 & 0.197 \\
\hline C22: $5 \mathrm{n} 3$ & $0.61^{\mathrm{bc}}$ & $0.44^{\mathrm{c}}$ & $0.65^{\mathrm{bc}}$ & $0.72^{\mathrm{b}}$ & 0.053 \\
\hline
\end{tabular}

${ }^{\mathrm{a}} \mathrm{BG}=$ basal diet $(\mathrm{BD})$ supplemented with bermudagrass hay; $\mathrm{SL}=\mathrm{BD}$ supplemented with sericea lespedeza; $\mathrm{PB}=\mathrm{BD}$ supplemented with pine bark; $\mathrm{SL}+\mathrm{PB}=\mathrm{BD}$ supplemented with combined SL and $\mathrm{PB} .{ }^{\mathrm{b}, \mathrm{d}} \mathrm{W}$ Within a row, least squares means that do not have a common letter differ $(P<0.05)$.

(BG) and high CT-containing supplements (SL, PB, and SL + PB). Compared with goats fed the SL supplement, goat fed the PB supplement had a lower $(P<$ 0.05) C18: 1n9 acid levels in the LM, whereas goats fed the mixed (SL + PB) sup- 
plement had higher $(P<0.05)$ levels of C20: $1 \mathrm{n} 9$ and C20: 5n 3 acids.

Twenty-seven fatty acids identified in kidney and subcutaneous fats from goats fed with four different dietary supplements were also divided into three major groups: SFA, MUFA and PUFA (Table 5). In the SFA (C10:0, C12:0,

Table 5. Least squares means $(n=6)$ of fatty acids (weight percent of fatty acid methyl esters) within kidney and subcutaneous fat depots of Kiko crossbred intact meat goats fed different dietary supplements ${ }^{\mathrm{a}}$ containing concentrated tannins (CT).

\begin{tabular}{|c|c|c|c|c|c|c|c|c|c|c|}
\hline \multirow{2}{*}{ Fatty acid, \% } & \multicolumn{5}{|c|}{ Kidney fat } & \multicolumn{5}{|c|}{ Subcutaneous fat } \\
\hline & BG & SL & $\mathrm{PB}$ & $\mathrm{SL}+\mathrm{PB}$ & SE & BG & SL & $\mathrm{PB}$ & $\mathrm{SL}+\mathrm{PB}$ & SE \\
\hline C10:0 & 2.53 & 2.01 & 2.30 & 2.34 & 0.301 & 2.54 & 2.66 & 2.62 & 2.53 & 0.392 \\
\hline $\mathrm{C} 12: 0$ & 1.75 & 1.73 & 1.26 & 1.64 & 0.122 & 0.69 & 1.05 & 1.04 & 0.74 & 0.286 \\
\hline C13:0 & $0.24^{\mathrm{b}}$ & $0.17^{\mathrm{c}}$ & $0.20^{\mathrm{bc}}$ & $0.19^{\mathrm{bc}}$ & 0.014 & 0.46 & 0.56 & 0.57 & 0.49 & 0.171 \\
\hline $\mathrm{C} 13: \ln 9$ & 0.27 & 0.22 & 0.25 & 0.24 & 0.014 & 0.21 & 0.34 & 0.37 & 0.26 & 0.148 \\
\hline C14:0 & 0.53 & 0.48 & 0.49 & 0.51 & 0.035 & 3.34 & 5.09 & 4.93 & 3.50 & 0.547 \\
\hline $\mathrm{C} 14: \ln 5$ & $0.29^{\mathrm{b}}$ & $0.24^{\mathrm{c}}$ & $0.27^{\mathrm{bc}}$ & $0.25^{\mathrm{bc}}$ & 0.010 & 0.49 & 0.57 & 0.52 & 0.48 & 0.287 \\
\hline C15:0 & 0.05 & 0.08 & 0.09 & 0.08 & 0.009 & 0.67 & 0.62 & 0.75 & 0.64 & 0.162 \\
\hline $\mathrm{C} 16: 0$, iso & $0.35^{\mathrm{b}}$ & $0.09^{c}$ & $0.09^{c}$ & $0.12^{\mathrm{c}}$ & 0.020 & 1.03 & 1.03 & 0.95 & 0.83 & 0.140 \\
\hline $\mathrm{C} 16: 0$ & $19.60^{\mathrm{b}}$ & $19.31^{\mathrm{b}}$ & $19.54^{\mathrm{b}}$ & $16.76^{\mathrm{c}}$ & 0.664 & 21.25 & 20.23 & 19.61 & 20.85 & 0.739 \\
\hline C16: 1n7, trans & 0.53 & 0.50 & 0.40 & 0.49 & 0.039 & 0.63 & 0.68 & 0.84 & 0.62 & 0.074 \\
\hline C16: $\ln 7$ & $2.21^{b c}$ & $1.89^{\mathrm{cd}}$ & $2.26^{\mathrm{b}}$ & $1.79^{\mathrm{d}}$ & 0.083 & 2.17 & 2.11 & 2.82 & 2.18 & 0.189 \\
\hline $\mathrm{C} 17: 0$ & $0.74^{\mathrm{b}}$ & $0.58^{c}$ & $0.70^{\mathrm{b}}$ & $0.61^{\mathrm{c}}$ & 0.019 & $1.88^{\mathrm{bc}}$ & $2.06^{\mathrm{bc}}$ & $3.19^{\mathrm{b}}$ & $1.61^{\mathrm{c}}$ & 0.332 \\
\hline $\mathrm{C} 17: \ln 7$ & $0.45^{\mathrm{b}}$ & $0.36^{\mathrm{c}}$ & $0.33^{c}$ & $0.33^{\mathrm{c}}$ & 0.019 & 0.45 & 0.55 & 0.35 & 0.33 & 0.118 \\
\hline C18:0 & 35.44 & 35.81 & 36.11 & 34.25 & 1.266 & $14.67^{\mathrm{b}}$ & $13.73^{\mathrm{bc}}$ & $9.12^{\mathrm{c}}$ & $15.90^{\mathrm{b}}$ & 1.548 \\
\hline C18: $1 \mathrm{n} 9$, trans & $6.51^{\mathrm{c}}$ & $6.67^{\mathrm{c}}$ & $9.27^{\mathrm{b}}$ & $8.31^{\mathrm{bc}}$ & 0.630 & 2.51 & 2.62 & 2.65 & 2.68 & 0.159 \\
\hline C18: $\ln 9$ & 22.73 & 21.60 & 19.72 & 21.01 & 0.794 & 40.30 & 38.19 & 40.95 & 38.17 & 1.723 \\
\hline C18: $1 \mathrm{n} 11$, trans & $0.50^{\mathrm{c}}$ & $0.55 b^{c}$ & $0.66^{\mathrm{b}}$ & $0.61 b^{c}$ & 0.030 & $0.78^{\mathrm{bc}}$ & $0.78^{\mathrm{bc}}$ & $1.03^{\mathrm{b}}$ & $0.74^{\mathrm{c}}$ & 0.061 \\
\hline $\mathrm{C} 18: 2 \mathrm{n} 6$ & $2.50^{\mathrm{c}}$ & $4.55^{\mathrm{b}}$ & $5.48^{\mathrm{b}}$ & $4.33^{\mathrm{c}}$ & 0.313 & $1.48^{\mathrm{c}}$ & $2.42^{\mathrm{bc}}$ & $2.22^{\mathrm{bc}}$ & $2.75^{\mathrm{b}}$ & 0.288 \\
\hline $\mathrm{C} 18: 2, C L A$ & $0.62^{\mathrm{c}}$ & $0.86^{\mathrm{b}}$ & $0.81^{b c}$ & $0.79^{\mathrm{bc}}$ & 0.049 & 0.44 & 0.65 & 0.54 & 0.59 & 0.045 \\
\hline $\mathrm{C} 18: 3 \mathrm{n} 3$ & 0.67 & 0.66 & 0.85 & 0.86 & 0.063 & 0.98 & 0.89 & 1.27 & 1.18 & 0.111 \\
\hline C20:0 & 0.09 & 0.11 & 0.13 & 0.12 & 0.007 & 0.11 & 0.13 & 0.11 & 0.10 & 0.011 \\
\hline C20: $\ln 9$ & $0.05^{\mathrm{c}}$ & $0.07^{\mathrm{bc}}$ & $0.08^{\mathrm{b}}$ & $0.08^{\mathrm{bc}}$ & 0.005 & 0.07 & 0.07 & 0.09 & 0.08 & 0.014 \\
\hline C20: 3n6 & 0.61 & 0.71 & 0.81 & 0.73 & 0.049 & 0.37 & 0.45 & 0.35 & 0.35 & 0.044 \\
\hline $\mathrm{C} 20: 4 \mathrm{n} 6$ & 0.46 & 0.41 & 0.38 & 0.43 & 0.002 & 1.70 & 1.73 & 2.14 & 1.60 & 0.225 \\
\hline $\mathrm{C} 20: 5 \mathrm{n} 3$ & 0.26 & 0.22 & 0.25 & 0.23 & 0.011 & 0.24 & 0.30 & 0.21 & 0.22 & 0.045 \\
\hline C22:0 & 0.18 & 0.22 & 0.27 & 0.30 & 0.035 & 0.31 & 0.33 & 0.43 & 0.35 & 0.037 \\
\hline $\mathrm{C} 22: 5 \mathrm{n} 3$ & 0.12 & 0.10 & 0.10 & 0.09 & 0.010 & $0.27^{\mathrm{bc}}$ & $0.18^{c}$ & $0.37^{\mathrm{b}}$ & $0.24^{\mathrm{bc}}$ & 0.031 \\
\hline
\end{tabular}

${ }^{\mathrm{a}} \mathrm{BG}=$ basal diet $(\mathrm{BD})$ supplemented with bermudagrass hay; $\mathrm{SL}=\mathrm{BD}$ supplemented with sericea lespedeza; $\mathrm{PB}=\mathrm{BD}$ supplemented with pine bark; $\mathrm{SL}+\mathrm{PB}=\mathrm{BD}$ supplemented with combined SL and $\mathrm{PB} .{ }^{\mathrm{b}, \mathrm{c}, \mathrm{d}}$ Within a row, least squares means that do not have a common letter differ $(P<0.05)$. 
C13:0, C14:0, C15:0, C16:0 iso, C16:0, C17:0, C18:0, C20:0 and C22:0) portion, significant differences were found in the mean concentrations of tridecanoic (C13:0), iso-palmitic (C16:0 iso), C16:0 and margaric (C17:0) acids in the kidney fats from goats fed the experimental supplementations; moreover, the mean concentrations of $\mathrm{C} 17: 0$ and C18:0 acids were also different $(P<0.05)$ in the subcutaneous fats. Compared with goats fed the control supplement (BG-diet), goats supplemented with SL had lower $(P<0.05)$ concentrations of C13:0, C16:0 iso and C17:0 acids in the kidney fats, and goats fed with $\mathrm{PB}$ and mixed (SL + $\mathrm{PB}$ ) supplements had also lower concentrations of C16:0 iso and C17:0 and $\mathrm{C} 16: 0$ iso acids, respectively. In the subcutaneous fat, goats fed the PB supplement had a higher percentage of $\mathrm{C} 17: 0$ than those fed the combined $(\mathrm{SL}+\mathrm{PB})$ supplement, but none of the CT-containing supplements was different from the control ones. Mean percentage of C18:0 in goats fed the PB supplement was lower $(P<0.05)$ than those fed the control (BG). Of the MUFA (C13: $\ln 9$ C14: 1n5, C16:1 trans, C16: 1n7, C17: 1n7, C18: 1n9 trans, C18: 1n9, C18: 1n11 trans and C20: $1 n 9)$, differences $(P<0.05)$ were found in the mean concentrations of myristoleic (C14: 1n5), palmitoleic (C16: 1n7), heptadecenoic (C17: 1n7), C18: 1n9 trans, C18: $1 \mathrm{n} 11$ trans and C20: $1 \mathrm{n} 9$ acids in the kidney fats from goats fed four different dietary supplements; moreover, the mean concentration of C18: 1n9 trans acid was also different $(P<0.05)$ in the subcutaneous fats. Compared with goats fed the control, goats supplemented with SL had lower $(P<0.05)$ concentrations of C14: 1n5 and C17: $1 \mathrm{n} 7$ acids in the kidney fats; moreover, goats fed with $\mathrm{PB}$ and mixed $(\mathrm{SL}+\mathrm{PB})$ supplements had also lower $(P<0.05)$ concentrations of $\mathrm{C} 17: \ln 7$ and $\mathrm{C} 16: \ln 7$ and $\mathrm{C} 17: \ln 7$ acids, respectively. However, goats supplemented with $\mathrm{PB}$ had higher $(P<0.05)$ concentrations of C18: $\ln 9$ trans, C18: $\ln 11$ trans and C20: $\ln 9$ acids in the kidney fats than goats fed the control (BG-supplement). In the subcutaneous fats, goats fed the PB supplement had a higher $(P<0.05)$ percentage of C18: $1 \mathrm{n} 11$ trans than those fed the mixed $(\mathrm{SL}+\mathrm{PB})$ supplement, but none of the CT-containing supplements was different from the control ones. In the PUFA (C18: 2n6, C18:2 CLA, C18: 3n3, C20: 3n6, C20: 4n6, C20: 5n3 and C22: 5n3) portion, significant differences were found in the mean concentrations of C18: $2 \mathrm{n} 6$ and conjugated linoleic (C18:2 CLA ) acids in the kidney fats from goats fed the experimental diets; moreover, the mean concentrations of C18:2 $C L A$ and C22: $5 \mathrm{n} 3$ acids were also different $(P<0.05)$ in the subcutaneous fats. Compared with goats fed the control, goats supplemented with SL had higher $(P<0.05)$ concentrations of C18: 2n6 and C18:2 CLA acids in the kidney fats, and goats fed with $\mathrm{PB}$ supplement also had a higher $(P<0.05)$ concentration of C18: 2 n6 acid. In subcutaneous fat, goats fed the combined $(\mathrm{SL}+\mathrm{PB})$ supplement had a higher $(P<0.05)$ percentage of C18: 2 n6 than those fed the control, but neither of the CT-containing supplements was different. Furthermore, goats fed the PB supplement had a higher $(P<0.05)$ percentage of $\mathrm{C} 22: 5 \mathrm{n} 3$ than those fed the SL supplement, whereas none of the CT-containing supplements were different from the control ones. 


\section{Discussion}

No differences $(P>0.10)$ in the ADG and final weight of the goats fed the control (BG) and three different CT containing supplements (SL, PB, and SL + PB) indicated that meat goats tended to tolerate and perform well when consuming CT from either forage-, wood-derived products, or their mixed CT products. In general, feeding forages containing high concentrations of CT has been reported to restrict intake and reduce overall weight gain by livestock [21]. However, Min et al. [22] suggested that feeding CT containing plants increases rumen bypass proteins, thereby counteracting proteins become available for digestion. Such mechanism to increased rumen bypass leading to more efficient utilization of protein due to the action of $\mathrm{CT}$ in the supplementations was not revealed in the present study because further improved performance of the CT supplemented goats was not found in this present feeding trial. Results of the present study differ from those of Hoskin et al. [23] who reported that lambs fed high-CT containing forages (up to $8 \% \mathrm{DMCT}$ ) were heavier at slaughter than those fed forages containing no detective CT. However, it is not clearly understood how CT affect carcass traits.

The ultimate muscle $\mathrm{pH}$ is important for fresh meat due to its effect on shelf life, color, and quality of fresh meat. In the present study, ultimate $\mathrm{pH}$ in the longissimus muscle (LM) of meat goats was not significantly affected by the CT containing supplements (Table 3). On the contrary, a significant difference in the ultimate $\mathrm{pH}$ of $\mathrm{LM}$ was observed in lambs fed the tannin-containing diet [24]; moreover, high ultimate $\mathrm{pH}$ in the LM from lambs fed the tannin-containing diet might be associated with malnutrition and stress in general [25]. However, such detrimental effects on the performance of experimental goats were not observed in the present study. Previous data [26] and our findings indicated that meat goats more easily overcome the negative impacts of CT on ruminant digestion tracts compared with sheep and cattle.

The visual appearance of fresh meat is based on color, marbling and water-holding capacity [27]. Changes in meat color are closely associated with lipid and pigment oxidation, as well as with microbial load [28]. Yet the mechanism of condensed-tannins on fresh meat color is not clearly defined. In the present study, all three CIE L* (lightness), $\mathrm{a}^{\star}$ (redness) and $\mathrm{b}^{\star}$ (yellowness) color coordinate values of the LM in meat goats were significantly influenced by feeding dietary CT supplements (Table 3). Priolo et al. [24] reported that the LM from lambs fed carob pulp (tannin-enriched diet; $2.5 \%$ DM CT) had a lighter color (higher $\mathrm{CIE} \mathrm{L}^{*}$ value) of LM with decreased blood hemoglobin concentrations compared with those fed diets containing no detective CT. Furthermore, the authors suggested that the reduction of hemoglobin and myoglobin in LM from CT fed lambs could account for the differences in color; however, no differences in the redness (CIE $\mathrm{a}^{*}$ value) and yellowness (CIE $\mathrm{b}^{*}$ value) of LM were detected in their study. In the present study, higher CIE $\mathrm{a}^{\star}$ (redness) and $\mathrm{b}^{\star}$ (yellowness) values in PB supplemented goats could not be fully explained by the hypothesis 
from Priolo et al. [24]. To that end, further investigation is needed to better understand the effect of dietary CT on the fresh meat color of small ruminants.

Myoglobin ( $\mathrm{Mb}$ ) contents in the LM from meat goats were not changed in this study (Table 3). According to Wan Zabari and Wahid [29], Mb contents of crossbred goats ranged from 3.11 to $6.49 \mathrm{mg} / \mathrm{g}$ flesh, where the mean ranges of $\mathrm{Mb}$ in the present study were $4.04-5.40 \mathrm{mg} / \mathrm{g}$ fresh meat (Table 3). Several live animal-related factors including species, maturity, sex, and muscle groups are known to influence $\mathrm{Mb}$ contents in general [30]. In fresh-cut meat, $\mathrm{Mb}$ can exist in any of the three redox forms, mainly deoxymyoglobin (DeoxyMb), oxymyoglobin (OxyMb), and metmyoglobin (MetMb), and their proportions depend on the levels of saturation $\mathrm{Mb}$ with oxygen [31]. Formation of brown MetMb is occurred in the interior of the fresh meat because of the lack of oxygen penetrating below the surface. Such low oxygen concentrations may induce oxidation of $\mathrm{Mb}$ to MetMb that is associated with meat discoloration [32]. In the present study, the increments of MetMb concentrations and thiobarbituric acid reactive substances (TBARS) values were observed in the LM from goats fed the PB supplemented diet (Table 3). Perhaps MetMb reducing enzyme systems in the LM from PB-fed goats were disrupted, followed by slow conversion of MetMb into DeoxyMb, and subsequently accumulated MetMb upon analyzing. In general, TBARS are useful to determine the degree of lipid oxidation occurred in meat products. Furthermore, lipid oxidation results in the production of free radicals, which may lead to the oxidation of meat pigments and the generation of rancid odors and flavors [33]. Higher TBAR values in LM were not expected in loin chops from goats fed the PB-diet, which is known to retard the rate of lipid oxidation due to the accumulation of phenolic compounds derived from the PB. Several researchers reported a strong relationship between lipid oxidation and myoglobin oxidation [34] [35]. Our results confirmed this relationship only in the LM from PB-fed goats, which exhibited higher myoglobin oxidation and lipid oxidation levels. However, in the present study, it remains unclear why higher MetMb concentrations and TBAR values were observed in loin chops from PB- fed goats as compared to those from goats fed the other three diets.

There were no dietary supplementation effects on meat water holding capacity as measured by cooking loss (Table 3). However, significant differences were found in the Warner-Bratzler shear force (WBSF) values of loin chops from goats fed the four different dietary supplements (Table 3). Chops from goats fed the control (BG-supplement), containing negligible amounts of CT, had higher $(P<0.002)$ WBSF values than those from goats fed either SL- or PB-supplement, containing relatively high amounts of CT. Similar results were reported by Priolo et al. [24] in lambs, who reported that CT-containing dietary regimen positively influenced the tenderness of lamb without changing its water holding capacity. In the present study, incorporating the higher CT concentration in the experimental diets affected the eating quality of chevon (Table 3 ). The acceptable limit for lamb toughness is about a $3 \mathrm{~kg}$ Warner-Bratzler shear force (WBSF) 
for Australian and New Zealand consumers [36], whereas the toughness value of chevon from the present study was over this acceptable limit (Table 3). Many internal and external factors influence the shear force values of meat, such as the treatment of animals prior to slaughter, post-mortem methodologies, the sampled muscle, and method of sample preparation; moreover, fiber type and total and soluble collagen contents mainly affect sensory tenderness of meat [36]. Priolo et al. [24] noted that feeding tannin containing diets increased the ultimate $\mathrm{pH}$ of fresh lamb by reducing the shear force of cooked lamb, which corresponded to reports of reduced shear force for muscle with high ultimate $\mathrm{pH}$ [37]. Such a trend was not found in the present study, but the reason for the discrepancy is not known at this time. Perhaps relatively high CT-containing diets affected the collagen content and solubility in chevon because nutritional factors can influence the functional property of collagen [38]. However, it is not fully understood how CT affects the collagen content and solubility in muscle.

In general, the proximate composition of muscle in livestock is influenced by diet and breed, as well as age and gender [39]. Development of muscle depends on nutrient composition and utilization; therefore, the energy contents of the diet might partially explain the difference in the chemical composition of muscle [39]. In the present study, meat goats were offered isonitrogen and isoenergy diets, thereby expecting no difference in the proximate composition of LM from the meat goats, especially protein and fat contents (Table 4). Priolo et al. [40] reported that Longissimus dorsi (LD) muscle from lambs fed fresh sulla either with or without polyethylene glycol (PG; a binding agent that eliminates the effects of CT) was not significantly different in proximate composition. The results of their study contradict those of Barry et al. [41] who reported a lower percentage of fat and a higher content of crude protein in LM from tannin (Lotus pedunculatus)-fed lambs, compared with lambs fed the same diet supplemented with PG. This trend was expected because of inducing to decrease ruminal protein degradation and to improve the efficiency of dietary protein by the action of $\mathrm{CT}$ in the SL and PB. However, such a trend was not observed in the present study.

In general, ruminant products such as meat and milk contain high levels of SFA and lower levels of PUFA [42]. However, fresh meat from pasture-raised ruminants generally contains a higher concentration of PUFA than that from concentrated fed ruminants [36]. According to Webb et al. [36], the current recommendation by health professionals for a PUFA/SFA ratio is approximately 0.45 because of the negative effects of dietary saturated fats on human health, whereas the PUFA/SFA ratios ( 0.23 to 0.31 ) in the present study were lower than the recommended ratio (Table 4). Efforts to increase the concentrations of PUFA in ruminant meat and milk had very limited successes because ruminal microorganisms hydrogenate PUFA during digestion [43]. Several feeds containing tannins were supplemented to increase PUFA contents including C18:2 $C L A$ (rumenic acid) in ruminant meat and milk [44], through the manipulation 
of ruminal biohydrogenation. From the ruminal biohydrogenation of C18 PUFA (linoleic and linolenic acids), a large amount of trans forms of C18:1 isomers are derived and accumulated in animal tissues [41]. However, tannins are phenolic compounds that limit the activity of ruminal biohydrogenation in vitro studies [44] [45] and increase muscle $\Delta 9$-desaturatase protein expression [44] ruminal microorganisms during digestion. Furthermore, a large portion of vaccenic (C18: 1n11 trans) acid generated from ruminal microorganisms can be partially converted to C18:2 CLA (rumenic acid) in the edible tissues of ruminants by the action of $\Delta 9$-desaturatase enzyme. Because of the suppression of ruminal biohydrogenation, C18: $2 \mathrm{n} 6$ and C18: $3 \mathrm{n} 3$ acids were present at higher concentrations in the muscle of $\mathrm{PB}$-supplemented goats when compared with those fed tannin-free supplements (control or BG-supplement). However, vaccenic (C18: 1n11 trans) acid was present at a higher concentration in the muscle of PB-supplemented goats when compared with those fed tannin-free supplements (Table 4). Perhaps the vaccenic acid from ruminal biohydrogenation in the present study might be not completely converted to rumenic acid (C18:2 CLA) in the muscle from goats supplemented with the PB in the present study. Furthermore, C18: 1n9 trans acid was also present at higher concentration in the muscle of PB-supplemented goats when compared with those fed tannin-free or SL supplements, whereas C18:0 acid was lower in the muscle of goats fed either PB or SL supplements because dietary condensed tannins might reduce the ruminal biohydrogenation during the digestion (Table 4). In the present study, tannin-containing supplements also increase percentages of trans forms of C18:1 isomers and C18 PUFA in the kidney fats, compared with those of goats fed tannin-free supplements, whereas there was no tendency to increase these C18 fatty acids in the subcutaneous fats (Table 5). Hence, the reduction of ruminal biohydrogenation induced by CT-containing supplements in the present study was enough to modify the fatty acid profiles of the muscle and kidney fats, but not subcutaneous fats. Furthermore, it suggested that dietary condensed tannins from pine bark might provide a more predominated effect on ruminal biohydrogenation than those from either sericea lespedeza alone or combined with pine bark.

\section{Conclusion}

It is commonly believed that higher amounts of condensed tannins can have deleterious effects on animal performances due to reducing protein degradation in the rumen. However, supplementing tannins in ruminant diets has the potential to increase unsaturated fatty acids in edible tissues via modifying ruminal microbial activities. Supplementing meat goats with forage (sericea lespedeza) and wood-derived (pine bark) condensed tannins, as well as their combination properly maintained and regulated goats' performances without altering the chemical composition and quality characteristics of chevon compared with goats fed bermudagrass. Our findings indicate that either forage-, wood-derived condensed tannins, or their combined one can be used as a dietary supplement since 
they do not have any detrimental effect on meat goats' performances and meat quality characteristics of chevon. Furthermore, feeding meat goats with woodderived condensed tannins probably produced tenderer and healthier chevon than that from goats fed either forage-derived only or combined with forage and wood derived-condensed tannins, whereas there were no synergistic effects on meat quality properties of cheven from goats fed the combination of forage- and wood-derived condensed tannins.

\section{Acknowledgements}

This research was supported by the USDA-NIFA-Evan-Allen Research Program in Agricultural Research Station at Fort Valley State University (Fort Valley, GA, USA). The authors would like to thank the farm crew at Tuskegee University (Tuskegee, AL, USA) and the meat processing staff at Fort Valley State University.

\section{Conflicts of Interest}

The authors declare no conflicts of interest regarding the publication of this paper.

\section{References}

[1] Robinson, J. (2004) Pasture Perfect: The Far-Reaching Benefits of Choosing Meat, Eggs, and Dairy Products Form Grass-Fed Animals. Vashon Island Press, Vashon, $150 \mathrm{p}$.

[2] Ibrahim, M., Pattanaik, N., Onyango, B. and Liu, X. (2017) Factors Influencing Potential Demand for Goat Meats in Georgia. Journal of Food Distribution Research, 48, 93-98.

[3] Mahgoub, O., Kadim, I.T. and Webb, E.C. (2012) Goat Meat Production and Quality. The CAB International, London, CPIThe BSP Professional Book, London, 361 p. https://doi.org/10.1079/9781845938499.0000

[4] Miller, J.E. (1996) Controlling Goat Parasites in the Southeast. In: Southeast Region Meat Goat Production Symposium, Florida A\&M University, Tallahassee, 80-82.

[5] Min, B.R. and Hart, S.P. (2003) Tannins for Suppression of Internal Parasites. Journal of Animal Science, 81, E102-E109.

[6] Shaik, S.A., Terrill, T.H., Miller, J.E., Kouakou, B., Kannan, G., Kaplan, R.M., Burke, J.M. and Mosjidis, J.A. (2006) Sericea Lespedeza Hay as a Natural Deworming Agent against Gastrointestinal Nematode Infection in Goats. Veterinary Parasitology, 139, 150-157. https://doi.org/10.1016/j.vetpar.2006.02.020

[7] Moore, D.A., Terrill, T.H., Kouakou, B., Shaik, S.A., Mosjidis, J.A., Miller, J.E., Vanguru, M., Kannan, G. and Burke, J.M. (2008) The Effects of Feeding Sericea Lespedeza Hay on Growth Rate of Goats Naturally Infected with Gastrointestinal Nematodes. Journal of Animal Science, 86, 2328-2337. https://doi.org/10.2527/jas.2007-0411

[8] Puchala, R., Min, R.B., Goetsch, A.L. and Sahlu, T. (2005) The Effect of Condensed Tannin Containing Forage on Methane Emission by Goats. Journal of Animal Science, 83, 182-186. https://doi.org/10.2527/2005.831182x 
[9] Lee, J.H., Min, B.R. and Lemma, B.R. (2017) Quality Characteristics of Goat Meat as Influenced by Condensed Tannins-Containing Pine Bark. Small Ruminant Research, 146, 28-32. https://doi.org/10.1016/j.smallrumres.2016.11.009

[10] Coultrap, D.E., Fulgham, K.O., Lancaster, D.L., Gustafson, J., Lile, D.F. and George, M.R. (2008). Relationship between Western Juniper (Juniperus occidentalis) and Understory Vegetation. Invasive Plant Science and Management, 1, 3-11. https://doi.org/10.1614/IPSM-07-008.1

[11] Min, B.R., Solaiman, S., Gurung, N., Behrends, J., Eun, J.S., Taha, E. and Rose, J. (2012) Effects of Pine Bark Supplementation on Performance, Rumen Fermentation, and Carcass Characteristics of Kiko Crossbred Male Goats. Journal of Animal Science, 90, 3556-3567. https://doi.org/10.2527/jas.2011-4931

[12] Terrill, T.H., Rowan, A.M., Douglas, G.B. and Barry, T.N. (1992) Determination of Extractable and Bound Condensed Tannin Concentrations in Forage Plants, Protein Concentrate Meals and Cereal Grains. Journal of the Science of Food and Agriculture, 58, 321-329. https://doi.org/10.1002/jsfa.2740580306

[13] Makkar, H.P.S. (2003) Effects and Fate of Tannins in Ruminant Animals, Adaptation to Tannins, and Strategies to Overcome Detrimental Effects of Feeding Tannin-Rich Feeds. Small Ruminant Research, 49, 241-256. https://doi.org/10.1016/S0921-4488(03)00142-1

[14] Reed, J.D. (1995) Nutritional Toxicology of Tannins and Related Polyphenols in Forage Legumes. Journal of Animal Science, 73, 1516-1528. https://doi.org/10.2527/1995.7351516x

[15] McMillin, K.W. and Brock, A.P. (2005) Production Practices and Processing for Value-Added Goat Meat. Journal of Animal Science, 83, E57-E68.

[16] Krzywicki, K. (1982) The Determination of Haem Pigments in Meat. Meat Science, 7, 29-36. https://doi.org/10.1016/0309-1740(82)90095-X

[17] Buege, C.E. and Aust, S.D. (1978). Microsomal Lipid Peroxidation. Methods in Enzymology, 52, 302-304. https://doi.org/10.1016/S0076-6879(78)52032-6

[18] Association of Official Analytical Chemists (AOAC) (1995) Official Methods of Analysis of the AOAC International. 16th Edition, AOCS International, Gaithersburg.

[19] Lee, J.H., Kouakou, B. and Kannan, G. (2008) Chemical Composition and Quality Characteristics of Chevon From Goats Fed Three Different Post-Weaning Diets. Small Ruminant Research, 75, 177-184. https://doi.org/10.1016/j.smallrumres.2007.10.003

[20] American Oil Chemists' Society (AOCS) (1993) Official and Tentative Methods of Analysis. 5th Edition, AOCS, Champaign.

[21] Turner, K.E., Wildeus, S. and Collins, J.R. (2005) Intake, Performance, and Blood Parametersin Young Goats Offered High Forage Diets of Lespedeza or Alfalfa Hay. Small Ruminant Research, 59, 15-23. https://doi.org/10.1016/j.smallrumres.2004.11.007

[22] Min, B.R., Barry, T.N., Attwood, G.T. and McNabb, W.C. (2003) The Effect of Condensed Tannins on the Nutrition and Health of Ruminants Fed Fresh Temperature Forages: A Review. Animal Feed Science and Technology, 106, 3-19. https://doi.org/10.1016/S0377-8401(03)00041-5

[23] Hoskin, S.O., Barry, T.N., Wilson, P.R. and Kemp, P.D. (1999) Growth and Carcass Production of Young Farmed Deer Grazing Sulla (Hedysarum coronarium), Chicory (Cichorium intybus), or Perennial Ryegrass (Lolium perenne)/White Clover 
(Trifolium repnes) Pasture in New Zealand. New Zealand Journal of Agricultural Research, 42, 83-92. https://doi.org/10.1080/00288233.1999.9513356

[24] Priolo, A., Waghorn, G.C., Lanza, M., Biondi, L. and Pennisi, P. (2000) Polyethylene Glycol as a Means for Reducing the Impact of Condensed Tannins in Carob Pulp: Effects on Lamb Growth Performance and Meat Quality. Journal of Animal Science, 78, 810-816. https://doi.org/10.2527/2000.784810x

[25] Barry, T.N., Allsop, T.F. and Redekopp, C. (1986) The Role of Condensed Tannins in the Nutritional Value of Lotus pedunculatus for Sheep 5. Effects on the Endocrine System and on Adipose Tissue Metabolism. British Journal of Nutrition, 56, 607-614. https://doi.org/10.1079/BJN19860141

[26] Brooker, J.D., O’Donovan, L.A., Skene, I., Clarke, K., Blackall, L. and Muslera, P. (1994) Streptococcus caprine sp. Nov, a Tannin Resistant Ruminal Bacterium from Feral Goats. Letters in Applied Microbiology, 18, 313-318.

https://doi.org/10.1111/j.1472-765X.1994.tb00877.x

[27] Anderson, H.J., Oksbjerg, N., Young, J.F. and Therkildsen, M. (2005) Feeding and Meat Quality-A Future Approach. Meat Science, 70, 543-554.

https://doi.org/10.1016/j.meatsci.2004.07.015

[28] Granti, S., Angel, S., Akiri, B., Holzer, Z., Aharoni, Y., Orlov, A. and Kanner, J. (2001) Effects of Vitamin E Supplementation on Lipid Peroxidation and Color Retention of Salted Calf Muscle from a Diet Rich in Polyunsaturated Fatty Acids. Journal of Agricultural and Food Chemistry, 49, 5951-5956. https://doi.org/10.1021/jf010459s

[29] Wan Zabari, W.M. and Wahid, S.A. (1985) Mineral Concentrations in the Blood Plasma and Various Tissue of Local Crossbred Goats. Malaysian Agricultural Research and Development Institute (MARDI) Research Bulletin, 13, 333-340.

[30] Ledward, D.A. (1992) Color of Raw and Cooked Meat. In: Johnson, D.E., Knight, M.K. and Ledward, D.A., Eds., The Chemistry of Muscle-Based Foods, Royal Society of Chemistry, London, 128-129.

[31] Mancini, R.A. and Hunt, M.C. (2005) Current Research in Meat Color. Meat Science, 71, 100-121. https://doi.org/10.1016/j.meatsci.2005.03.003

[32] Ranken, M.D. (2000) Handbook of Meat Product Technology. Blackwell Science Ltd., London, 212 p.

[33] Melton, S.L., Amiri, M., Davis, G.W. and Backus, W.R. (1982) Flavor and Chemical Characteristics of Ground Beef from Grass-, Forage-Grain and Grain-Finished Steers. Journal of Animal Science, 55, 77-87. https://doi.org/10.2527/jas1982.55177x

[34] Faustman, C.R. and Cassens, R.G. (1990) The Biochemical Basis for Discoloration in Fresh Meat: A Review. Journal of Muscle Foods, 1, 217-243. https://doi.org/10.1111/j.1745-4573.1990.tb00366.x

[35] McKenna, D.R., Mies, P.D., Baird, B.E., Pfeiffer, K.D., Ellebracht, J.W. and Savell, J.W. (2005) Biochemical and Physical Factors Affecting Discoloration Characteristics of 19 Bovine Muscle. Meat Science, 70, 665-682. https://doi.org/10.1016/j.meatsci.2005.02.016

[36] Webb, E.C., Casey, N.H. and Simela, L. (2005) Goat Meat Quality. Small Ruminant Research, 60, 153-166. https://doi.org/10.1016/j.smallrumres.2005.06.009

[37] Devine, C.E., Graafhuis, A.E., Muir, P.D. and Chrystall, B.B. (1993) The Effect of Growth Rate and Ultimate $\mathrm{pH}$ on Meat Quality in Lambs. Meat Science, 35, 63-77. https://doi.org/10.1016/0309-1740(93)90070-X

[38] Crouse, J.D., Cross, H.R. and Seideman, S.C. (1985) Effects of Sex Condition, Ge- 
notype, Diet and Carcass Electrical Stimulation on the Collagen Content and Palatability of Two Bovine Muscles. Journal of Animal Science, 60, 1228-1234. https://doi.org/10.2527/jas1985.6051228x

[39] Wood, J.D., Richardson, R.I., Nute, G.R., Fisher, A.V., Campo, M.M., Kasapidou, E., Sheard, P.R. and Enser, M. (2003) Effect of Fatty Acids on Meat Quality: A Review. Meat Science, 66, 21-32. https://doi.org/10.1016/S0309-1740(03)00022-6

[40] Priolo, A., Bella, M., Lanza, M., Galofaro, V., Biondi, L., Barbagallo, D., Ben Salem, H. and Pennisi, P. (2005) Carcass and Meat Quality of Lambs Fed Fresh Sulla ( $\mathrm{He}-$ dysarum coronarium L.) with or without Polyethylene Glycol or Concentrate. Small Ruminant Research, 59, 281-288. https://doi.org/10.1016/j.smallrumres.2005.05.012

[41] Bessa, R.J.B., Alves, S.P., Jerònimo, E., Alfaia, C.M., Prates, J.A.M. and Santos-Silva, J. (2007) Effect of Lipid Supplements on Ruminal Biohydrogenation Intermediates and Muscle Fatty Acids in Lamb. European Journal of Lipid Science and Technology, 109, 868-883. https://doi.org/10.1002/ejlt.200600311

[42] Vanerveen, J.E. (1996) Dietary Recommendation for Lipids and Measure Designed to Facilitate Implementation. In: McDonald, R.E. and Min, D.B., Eds., Food Lipids and Health, Marcel Dekker, New York, 1-18.

[43] Scollan, N.D., Dhanoa, M.S., Choi, N.J., Maeng, W.J., Enser, M. and Wood, J.D. (2001) Biohydrogenation and Digestion of Long Chain Fatty Acids in Steers Fed on Difference Sources of Lipids. Journal of Agricultural Science, 136, 345-355. https://doi.org/10.1017/S0021859601008796

[44] Vasta, V., Mele, M., Serra, A., Scerra, M., Luciano, G., Lanza, M. and Priolo, A. (2009) Metabolic Fate of Fatty Acids Involved in Ruminal Biohydrogenation in Sheep Fed Concentrate or Herbage with or without Tannins. Journal of Animal Science, 87, 2674-2684. https://doi.org/10.2527/jas.2008-1761

[45] Khiaosa-Ard, R., Bryner, S.F., Scheeder, M.R.L., Wettstein, H.-R., Leiber, F., Kreuzer, M. and Soliva, C.R. (2009) Evidence for the Inhibition of the Terminal Step of Ruminal $\alpha$-Linolenic Biohydrogenation by Condensed Tannins. Journal of Dairy Science, 92, 177-188. https://doi.org/10.3168/jds.2008-1117 